Omni-Akuatika, 13 (2): $80-88,2017$
ISSN: 1858-3873 print / 2476-9347 online
Research Article

\title{
Food and Feeding Habits of Bilih Fish Mystacoleucus padangensis (Bleeker, 1852) In Naborsahan River, Toba Lake, North Sumatera
}

\author{
Ani Suryanti ${ }^{1}$, Sulistiono ${ }^{2}$, Ismudi Muchsin ${ }^{2}$, Endi Setiadi Kartamihardja ${ }^{3}$ \\ ${ }^{1}$ Marine Science and Fisheries Faculty, Raja Ali Haji Maritime University, Tanjung pinang, Indonesia \\ ${ }^{2}$ Departement of Aquatic Resources Management, Faculty of Fisheries and Marine Science Bogor Agricultural \\ University, Indonesia \\ ${ }^{3}$ Fishery Management and Conservation of Fish Resources Research Centers, Ministry of Marine and Fisheries, \\ Indonesia \\ "Corresponding author: yanti.ajb@gmail.com
}

Received 12 Juni 2017; Accepted 11 October 2017; Available online 28 November 2017

\begin{abstract}
The bilih fish (Mystacoleucus padangensis) is one kind of migratory fish from the lake to the river mainly supposed to spawn. This study aimed to determine food kinds and feeding time whenever they migrate. The study was conducted in Naborsahan River, Toba lake, North Sumatra. Sampling was conducted every 1 hour using Cast net. The results showed that $M$. padangensis keep doing the feeding activity and having diurnal when migrated. Natural food bilih fish that found in it intestine were phytoplankton include Rhizosolenia, Synedra, Gonatozygon, Closterium, Surirella, Pinnularia, Oscillatroria, Melosira, Gyrosigma, Aulacoseira and Zooplankton among others Creseis, Tubifex and Daphnia. The type of natural food that mostly found in $M$. padangensis intestines were phytoplankton from the genus Synedra sp (Bacilariopiceae) with Index of Preponderance (IP) is $97.9 \%$. Based on the composition of the natural food that was dominated, $M$. padangensis Biwas categorized asthe plankton feeder.
\end{abstract}

Keywords: bilih fish, diurnal, feeding habits, plankton feeder, Toba lake

\section{Introduction}

The bilih Fish (Mystacoleucus padangensis) is an endemic Cyprinidae fish from Singkarak Lake, West Sumatera that has been introduced to Toba Lake North Sumatera. (Umar \& Kartamihardja, 2011; Kottelat et al., 1996). However, now M. padangensis could be found in the Toba Lake. This fish was not a native species in Toba Lake, but it was introduced from Singkarak Lake, West Sumatra.

M. padangensis has very similar body shape to the relatives, namely genggehek fish (West Java) or wader fish (Central Java and East Java) that $M$. marginatus many in the inland water of Sumatra, Java, and Kalimantan. This fish was also similar to wader cakul fish (Central Java and East Java), beunter fish (West Java) or porapora fish (North Sumatra) that Puntius binotatus. Porapora fish in Toba Lake was never caught again since the 1990s, then the community around Toba lake called bilih fish as the porapora fish. Pora-pora name which was actually a $M$. padangensis stuck and popular until now (Kartamihardja and Sarnita, 2010).
The bilih fish grown rapidly in Toba Lake.It was provided with the data of bilih fish that been caught reached 30,000 ton in 2010 (Kartamihardja and Sarnita, 2010). Growth and development of biota in aquatic were mostly determined by the availability of natural feed and fish species that used it.The poor quality of water causes the water of the river unreasonable to be used (Yuliati et al., 2017). Temperature, dissolved oxygen and $\mathrm{pH}$ are important water quality parameters related to the life of aquatic organisms (Effendi, 2003; Sinaga et al., 2016). The study of food and feeding habits bilih fish in Toba Lake and in Singkarak Lake has been done by Purnomo (2008), Purnomo and Sunarno (2009), Umar and Kartamihardja (2011). But this study only analyzed the types of main food, complements food and supplements food for $M$. padangensis that caught in the lake. The study of feeding periodicity $M$. padangensis has never been done, as well as the study of food habits bilih fish that caught in the river has not be done. This was important because bilih fish migratory from the lake to the river to spawning. Whether this bilihfish eaten when migratory to spawn become one of information that needs to be related to fisheries biology. 


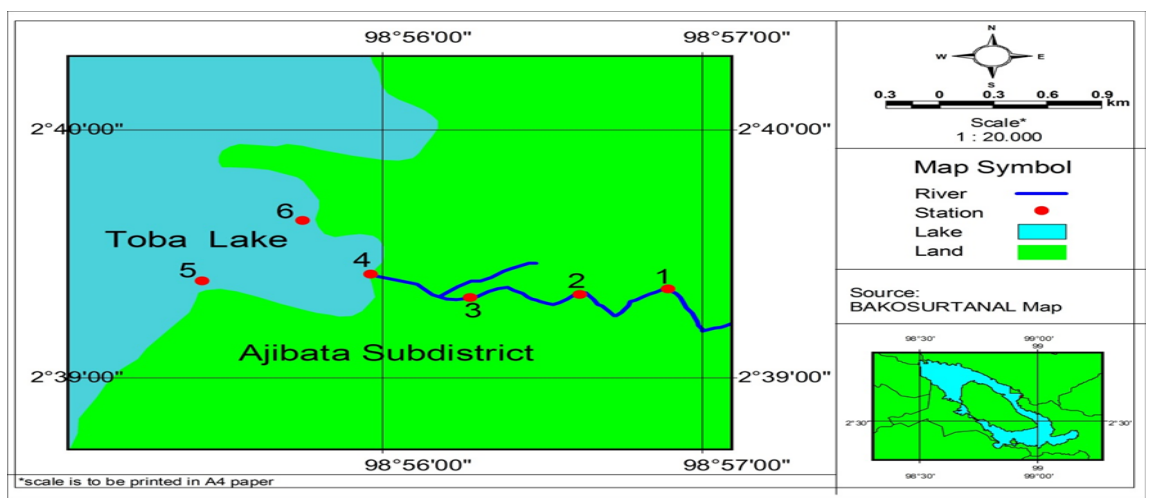

Figure 1. Sampling station at Naborsahan River Toba Lake North Sumatera

\section{Materials and Methods}

\section{Time and location of research}

This study was conducted in Naborsahan River, Toba Lake, Ajibata District, Toba Samosir Regency, North Sumatra. The sampling of the fish was carried out at six stations which were determined based on the river characteristics and bilih fish habitat (Figure 1). Sampling was carried out every month from April 2013 to May 2014. Sample analysis was done in Integrated Laboratory of Aquatic Resource Management Department, Faculty of Agriculture, University of North Sumatra.

\section{Research procedures}

The sampling was done once a month for 12 months. The sampling ofbilih fish once every 1 hour performed three times for the analysis of bilih fish feeding periodicity. The $M$. padangensis samples caught with Cast net. Samples have immediately measured the weight, then $1 \mathrm{ml}$ formalin $40 \%$ was injected to stop the metabolic rate of the fish. Furthermore, the sample was put in the bottle contain $10 \%$ formalin.

Food and feeding habits of the fish are determined by stomach analyses. Total length $(\mathrm{mm})$, wet weight $(\mathrm{g})$ and sex of each fish were recorded prior to the analysis of stomach. The digestive organs such as stomach (intestine) measured for lenght, weight and volume. After that, the intestinal contents of dissected fish is diluted with aquadest. Dilution is filtered and inserted into the sample bottle, and it is dropped by $4 \%$ formalin. Finally, observation of the intestinal contents is done using a stereoscopic microscope and then identified by using plankton identification book Sachlan (1982) and Edmonsond (1959) until the taxa most likely with $100 x$ magnification observation and repeated 3 times.

Index Stomach Content (ISC) is determined to find out the level of feed intake relative fish samples. ISC is determined by using the calculation according to Hyslop (1980), the formula:

$$
\mathrm{ISC}=\frac{\mathrm{SCW}}{\mathrm{BW}} \times 100
$$

Where, ISC = Index Stomach Content $(\%)$, SCW $=$ Total stomach contents weight $(\mathrm{g})$, $\mathrm{BW}=$ Total fish weight $(\mathrm{g})$.

Diet composition and determination of main food components $M$. padangensis known content analysis digestive tract (intestine). Calculation of the contents of the digestive tract is done by calculating the index of preponderance for composition analysis fullness level of natural food in the digestive tract of bilih fish. According to Natarjan and Jhingran (1961), it is calculated using the formula:

$$
\mathrm{IP}=\frac{\mathrm{Vi} \times \mathrm{Oi}}{\sum(\mathrm{Vi} \times \mathrm{Oi})} \times 100
$$

Where, IP = the main index (index of preponderance), $\mathrm{Vi}=$ percent volume of $\mathrm{a}$ particular food, $\mathrm{Oi}=$ percent incidence of some types of food, $\Sigma(\mathrm{Vi} \times \mathrm{Oi})=$ Total $\mathrm{Vi} \times \mathrm{Oi}$ of all kinds of food.

The abundance of plankton genus was counted at the station during the observation. Plankton abundance was calculated using an SRC with the following formula (APHA, 2005): 


$$
K=\frac{N \times A_{t} \times V_{t}}{A_{c} \times V_{s} \times A_{s}}
$$

Where, $\mathrm{K}=$ abundance phytoplankton (cell $\mathrm{L}^{-1}$ ) and zooplankton (indL ${ }^{-1}$ ), $N=$ number of plankton observed, As = volume of water that is filtered (L), At the surface SRC = crosssectional area $\left(\mathrm{mm}^{2}\right), A c=$ area of observation $\left(\mathrm{mm}^{2}\right), \mathrm{Vt}=$ volume concentrates on the bottle sample $(\mathrm{ml}), V_{\mathrm{s}}=$ volume of concentrate in $\mathrm{SRC}(\mathrm{ml})$

\section{Results and Discussion}

The results of stomach analysis of all the samples at the six stations of the study ( $n=$ 2,592 tail) showed that all bilih fish that caught during the day in a state of food. Bilih fish that was caught in the night showed the empty stomach. Based on the identification results showed that stomach contents consist of phytoplankton, zooplankton, tubifex and detritus.

The result of the calculation of hourly sampling Index Stomach Contents (ISC) can be seen in Figure 2. The value of ISC showed high percentages during the morning and low at night.

Based on Figure 2 indicates that the peak value of ISC on male and female fish that were in the morning is at 09:00 pm, based on observations in the field ISC rose from 06.00 $\mathrm{pm}$ and reached the peak at $09.00 \mathrm{pm}$ and began to decline from at 10:00 to $11: 00 \mathrm{pm}$. It tends to be stable at $11-15 \mathrm{pm}$ and began to rise again at $16: 00$ to $18: 00 \mathrm{pm}$. Stomach bilih fish atthis time tend to be empty. This show that bilih fish were diurnal, or active foraged during the day (diurnal). Stomach fullness index calculation is done to determine the relative food consumption of fish. Effendie (1997) stated that in normal conditions, the fish took food constantly.However, the intensity was not always the same because it depends on the index stomach contents. The fish that consumed intensively, then the stomach was always full while fish that consumed the food at any time, then the stomach would be filled in part.

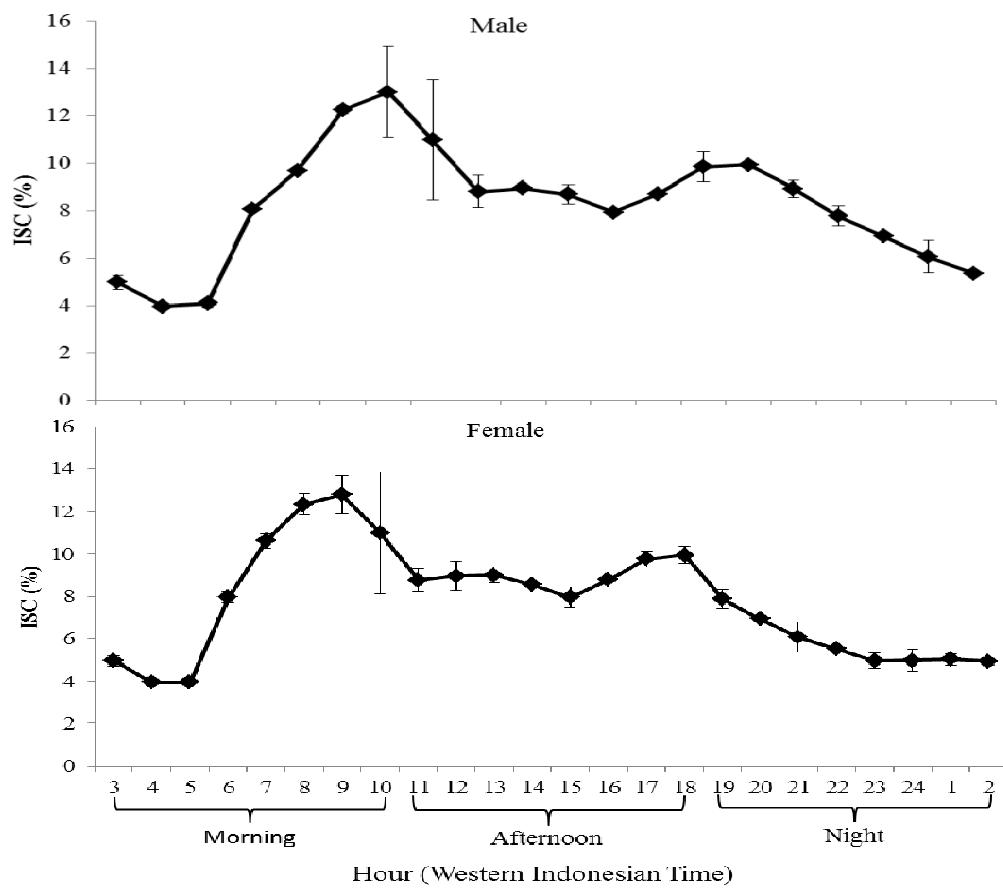

Figure 2. Index Stomach Contents (ISC) male and female M. padangensis

Figure 3 represent the results of the analysis of natural food in the stomach during research on the Naborsahan river, Index of Preponderance (IP) values obtained overall in the 2,592 sample bilih fish. Natural food was phytoplankton from the Bacillariophyceae class, Synedra genus was the most natural food often found in the intestines of bilih fish. The results of the analysis of natural food bilih fish by sex could be seen in Figure 4. The male and female 
bilih fish has the same kind of natural food in the form of phytoplankton (Bacillariophyceae Class). The Bacillariophyceae Class from
Genus Synedra was natural food types of bilih fish that often found in every research station

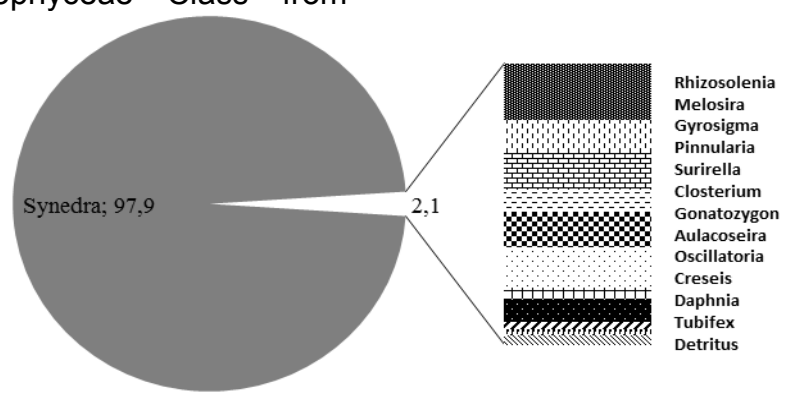

Figure 3. Composition of the natural food all sample $M$. padangensis
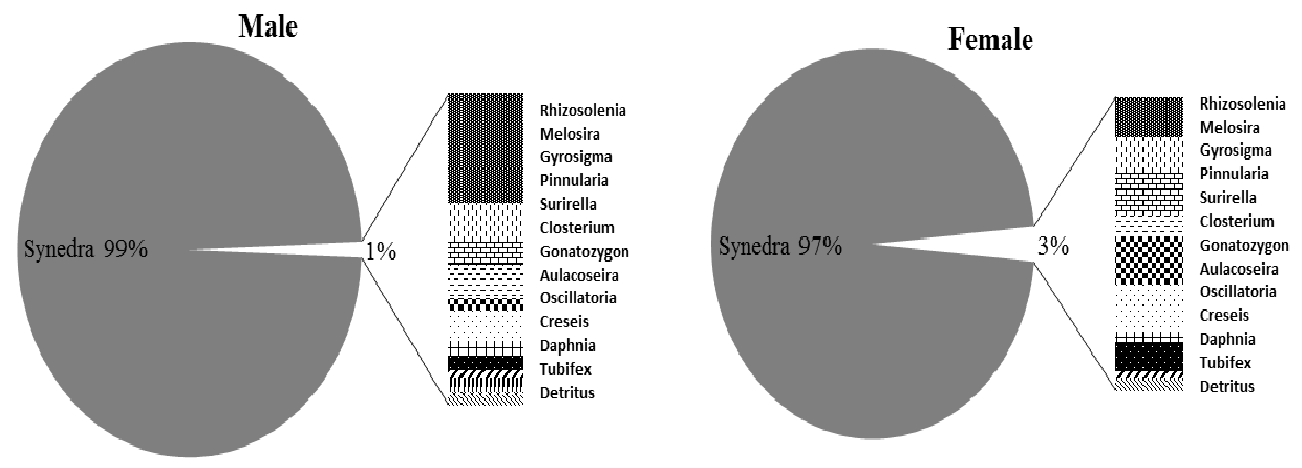

Figure 4. Composition of the natural food of $M$. padangensis by sex

Natural food of bilih fish on male and female fish was same (Figure 4). The difference on the percentage of each type of food naturally found in the intestines of $M$. padangensis. Synedra percentage dominate in fish intestines bilih both male and female. Synedra percentage in bilih fish males (99\%) and females $(97 \%)$. It showed that the Synedra as the main feed for bilih fish both male and female.

Figure 5 represents the Synedra percentage in intestines of bilih fish at the research station. The percentage Synedra in $M$. padangensis at Station 1 was $98 \%$, stations 2,3 , and 4 were $99 \%$, station 5 was $97 \%$ and station 6 was $96 \%$.

The food composition of $M$. padangensis in general (Figure 3, 4, 5) that found was groups of Bacillariophyceae wich was the natural food in bilih fish's intestines. This is consistent with thestatement Purnomo and Sunarno (2009) that the M. padangensis in Singkarak lake have the same natural food, such as phytoplankton most consumed by $M$. padangensis are family Bacillariophyceae. IP value of the Bacillariophyceae of the Synedra genus amounted to $98.9 \%$. This indicates that the Bacillariophyceae was the main food of bilih fish. Determination of the main food based on Nikolsky (1963) that IP> $40 \%$ was main food and $<40 \%$ was a complement food for the organism.

IP value of bilih fish male and female of to Bacillariophyceae respectively $98.9 \%$ and $98.7 \%$. Bacillariophyceae of the Synedra genus is a major food of $M$. padangensis (Figure 3, 4, $5)$. Males consumed the same food with the female fish. It showed no difference on natural food of $M$. padangensis male and female. This is along with Febriani (2010) which stated that a group of food from the digestive tract of male bilih fish not much different from the female $M$. padangensis Bacillaryophiceae group consisted of plankton, Chlorophyceae, Cyanophyceae, and others (litter, detritus, and organisms were not identified). 
Station 1

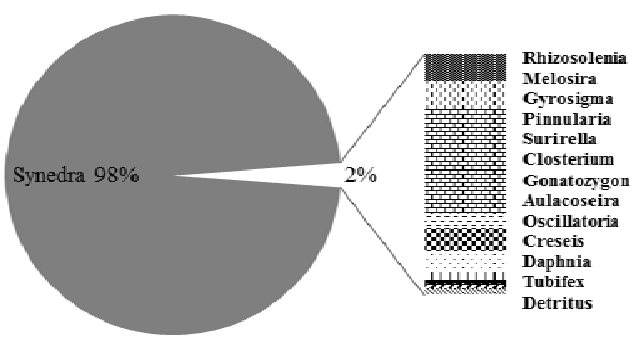

Station 3

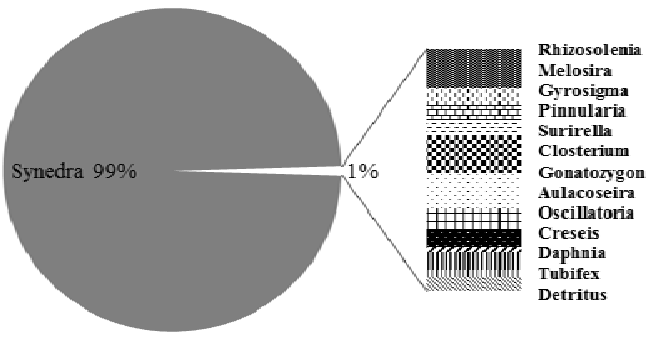

Station 5

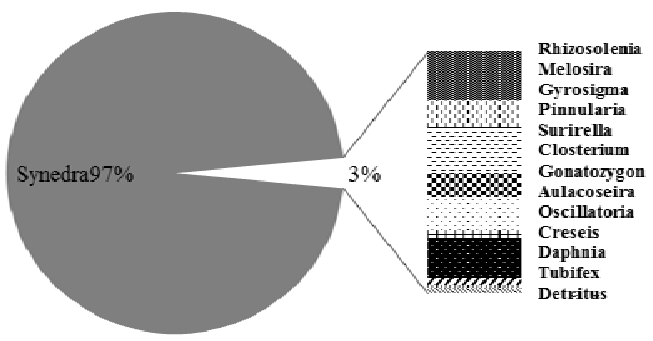

Station 2

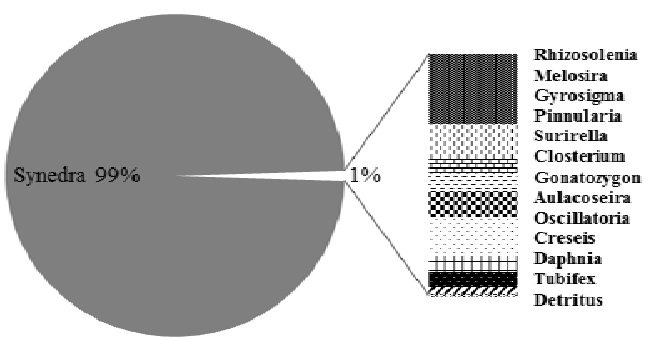

Station 4

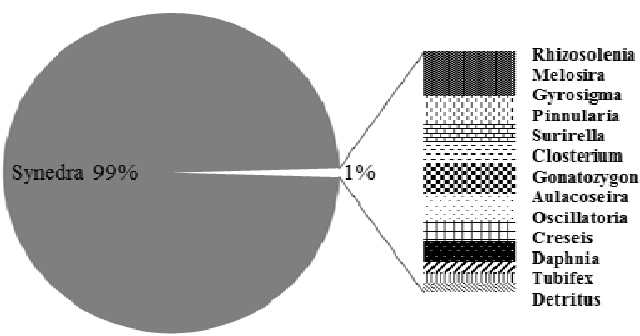

Station 6

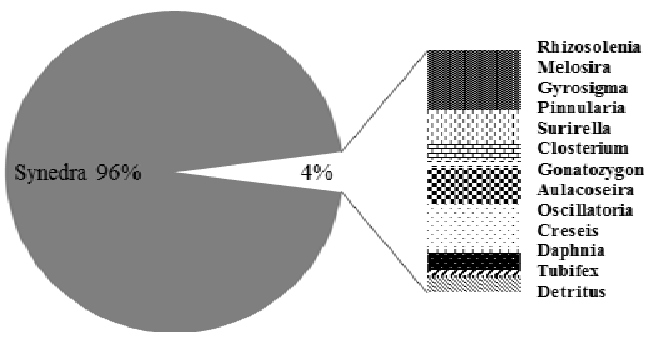

Figure 5. Composition of the natural food of $M$. padangensis at each research station

Figure 3 showed that the highest IP value in Bacilariopiceae Class was Synedra genus with IP value amounted to $98.9 \%$ and the lowest IP value for the Cladocera Class, Daphnia Genus with IP value of $0.001 \%$. According to Nikolsky (1963) the fish food that has an IP value $>40 \%$ then the organism categorized as the main food. IP Values $4-40 \%$ then the organism was the supplement food. IP value $<4 \%$ then these organisms was the complements food. Variations of $M$. padangensis food contained in Figure 3 and 4 showed that the main food of $M$. padangensis was a Synedra genus Bacillariopiceae Class which belong to the phytoplankton.

The results of this study were consistent with the results of Adjie (2009) on the same family of $M$. padangensis, for example, Semah Fish (Tor spp.). It showed the main food of Semah Fish form of moss with IP value by $80 \%$. Furthermore, the results of Taufiqurohman et al. (2007) in Cyprinidae Familly such as Nilem
Fish (Osteochillus hasselti) showed that Nilem Fish have the main food phytoplankton with IP value amounted to $76.63 \%$. Tresna et al. (2012) reported food habits of some fish that belongs to the Cyprinidae family, which Paray Fish (Rasbora aprotaenia) have the main food phytoplankton with IP value amounted to $55.22 \%$ supplement in the form of detritus with IP value amounted to $21.11 \%$ of zooplankton with IP value amounted to $12.6 \%$ and parts of plants with IP value amounted to $11.11 \%$ carp (Cyprinus carpio) have the main food zooplankton with IP value amounted to $80.00 \%$ supplement in the form of phytoplankton with the IP of $12.22 \%$ and detritus with IP amounted to $7.78 \%$, nilem fish have a main food phytoplankton value IP amounted to $79.00 \%$, the supplement food form part of the plant with IP value amounted to $12.78 \%$ and food complements such as zooplankton and detritus with IP value <4\%, Genggehek Fish ( $M$. marginatus) was a genus of $M$. padangensis 
have the main food phytoplankton with IP value of $62.78 \%$ and parts of plants with IP value amounted to $27.78 \%$, complements food in the form of detritus with IP value of $8.33 \%$ and supplement food such as zooplankton with IP value of $1.11 \%$.

The research result was slightly different fromthe results that reported by Umar and Kartamihardja (2011) which was the main food derived detritus $(78.8 \%)$, with complement food such as phytoplankton (11. 2\%) and zooplankton (8.0\%). Supplement food plant litter $(1.9 \%)$. The results obtained from the analysis of stomach contents of $M$. padangensis to sampling in 2009 at Toba lake. The results of observations in August 2010 acquired the main food in the form of detritus (92.9\%), complement food such as phytoplankton (4.9\%) and food supplement such as plant litter (1.8\%). Observations from the second period showed no difference on the type of fish bilih's food. The composition of $M$. padangensis food in Toba lakewas the same with the previous year as well as from the original habitat in Singkarak Lake West Sumatra. However, it was slightly different from composition percentage (Umar \& Kartamihardja, 2011).

The differences on the composition food were closely related to the age of the fish and the availability of natural food in the aquatic. The phytoplankton was a complementary food consumed was Milosira sp., Eunotia sp., and Synedra sp., from the Bacillariophyceae class (Umar \& Kartamihardja, 2011). Research at Singkarak Lake obtained the same results, which is the most phytoplankton that consumed by bilih fish is Bacillariophyceae (Purnomo and Sunarno, 2009). This situation was supported by the availability or abundance in nature, where the abundance of plankton in Singkarak lake dominated by Bacillariophyceae families (48. 6\%) (Purnomo, 2008).

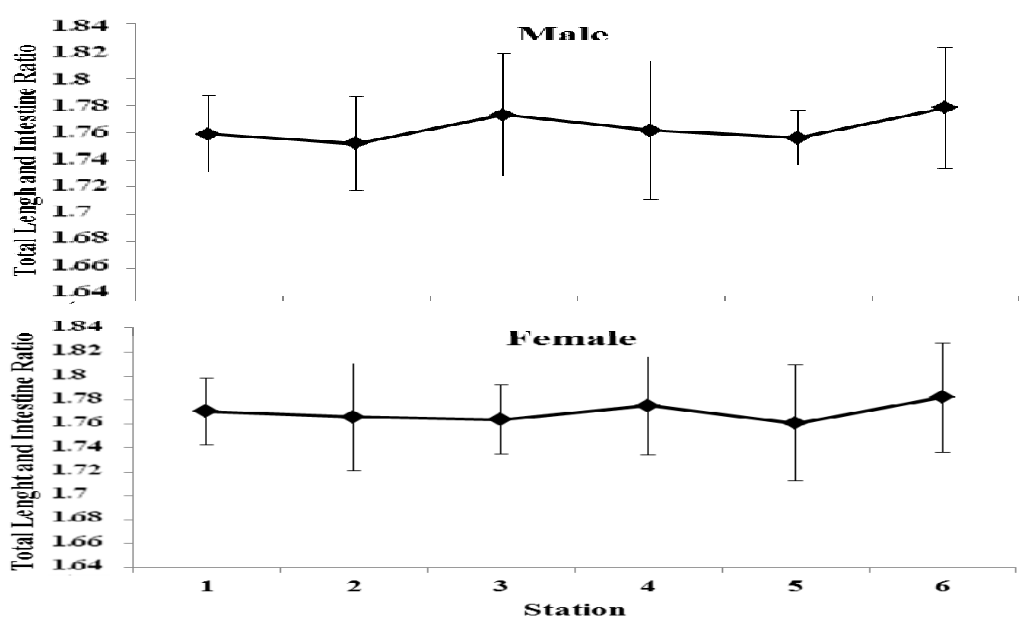

Figure 6.Total length and intestine ratio of bilih fish at each research station

Figure 6 indicates the ratio of the length of the intestine with a total length of bilih fish ranged 1.75-1.78. The results showed thatbilih fish have an intestine length longer than the length of the body. According to Situmorang (2013), a fish that has anatomical structure intestine length longer than the length of the body was a kind of herbivorous fish. The results of the comparison length of the intestine with a body length of this further strengthened that $M$. padangensis is omnivorous fish that tend herbivores. Effendie (1997) stated that the herbivorous fish generally did not have the stomach or the false hull with a very long intestine size could be several times their body length.
The main food of $M$. padangensis male and female fish were relatively similar in the composition was a plant-based form of phytoplankton. The main $M$. padangensis food fish in the Naborsahan river was phytoplankton. Differences occur only in the composition of animal food in the stomach male and female fish allegedly due to differences in fish habitat and availability of food in the water. The similarity of fish food is influenced by the species, availability, and eased of getting food, sex and the shape and condition of the aquatic. The composition of foods was the same male with female fish food. Similar results was also found in fish Leiognathus equulus (Simanjuntak and Rahardjo, 2008). 
Table1.The abundance of plankton at each research station

\begin{tabular}{|c|c|c|c|c|c|c|c|c|}
\hline \multirow[t]{2}{*}{ Class } & \multirow[t]{2}{*}{ Familly } & \multirow[t]{2}{*}{ Genus } & \multicolumn{6}{|c|}{ Abundance (celL ${ }^{-1}$ ) } \\
\hline & & & st 1 & st 2 & st 3 & st 4 & st 5 & st 6 \\
\hline \multicolumn{9}{|l|}{ Phytoplankton;1 } \\
\hline & Bacillariophyta & Achnanthes & 220 & 302 & 200 & 333 & 575 & 342 \\
\hline & & Bacillaria & 231 & 331 & 220 & 373 & 625 & 371 \\
\hline & & Cymbella & 162 & 287 & 160 & 264 & 500 & 257 \\
\hline & & Epithemia & 370 & 354 & 170 & 295 & 600 & 314 \\
\hline & & Fragillaria & 260 & 377 & 260 & 420 & 550 & 357 \\
\hline & & Frustulia & 430 & 356 & 230 & 404 & 600 & 357 \\
\hline & & Navicula & 250 & 352 & 280 & 467 & 775 & 357 \\
\hline & & Nitzschia & 256 & 281 & 210 & 264 & 375 & 285 \\
\hline & Chaetoceraceae & Rhizosolenia & 400 & 659 & 400 & 623 & 1125 & 657 \\
\hline & Fragillariaceae & Synedra & 450 & 953 & 450 & 934 & 1375 & 957 \\
\hline & Melosiraceae & Melosira & 310 & 429 & 310 & 498 & 900 & 428 \\
\hline & Naviculaceae & Gyrosigma & 260 & 347 & 260 & 358 & 725 & 342 \\
\hline & & Pinnularia & 280 & 527 & 280 & 529 & 800 & 528 \\
\hline & Surirellaceae & Surirella & 320 & 408 & 320 & 389 & 600 & 400 \\
\hline \multirow[t]{4}{*}{ Chlorophyceae } & Chlorophyta & Pediastrum & 200 & 387 & 200 & 467 & 575 & 385 \\
\hline & & $\begin{array}{l}\text { Scenedesm } \\
\text { us }\end{array}$ & 230 & 377 & 230 & 389 & 700 & 371 \\
\hline & Desmidiceae & Closterium & 210 & 348 & 210 & 451 & 475 & 342 \\
\hline & Gonatozygaceae & $\begin{array}{l}\text { Gonatozygo } \\
\mathrm{n}\end{array}$ & 320 & 488 & 320 & 389 & 700 & 428 \\
\hline \multirow[t]{2}{*}{ Coscinodiscophyceae } & Aulacoseiraceae & Aulacoseira & 250 & 378 & 250 & 389 & 700 & 371 \\
\hline & Bacillariophyta & $\begin{array}{l}\text { Coscinodisc } \\
\text { us }\end{array}$ & 200 & 349 & 200 & 358 & 600 & 342 \\
\hline \multirow[t]{2}{*}{ Cyanophyceae } & Cyanobacteria & Anabaena & 220 & 459 & 220 & 327 & 625 & 400 \\
\hline & Oscillatoriaceae & Oscillatoria & 260 & 445 & 260 & 420 & 700 & 400 \\
\hline \multirow[t]{2}{*}{ Zygnematophyceae } & Streptophyta & Cosmarium & 200 & 327 & 200 & 249 & 400 & 257 \\
\hline & & Pleurotenium & 180 & 245 & 180 & 234 & 450 & 285 \\
\hline unidentified & & & 90 & 124 & 90 & 155 & 175 & 114 \\
\hline Zooplankton & & & \multicolumn{6}{|c|}{ Abundance (indL ${ }^{-1}$ ) } \\
\hline Clacodera & Daphnidae & Daphnia & 7 & 7 & 2 & 3 & 4 & 5 \\
\hline Macrozoobentos & & & \multicolumn{6}{|c|}{ Abundance (indL ${ }^{-1}$ ) } \\
\hline Clitellata & Tubificidae & Tubifex & 7 & 5 & 3 & 3 & 3 & 2 \\
\hline Gastropoda & Cavollinidae & Creseis & 5 & 6 & 3 & 5 & 6 & 4 \\
\hline Total Abundance & & & 6,578 & 9,908 & 6,121 & 10,002 & 1,6638 & 19,668 \\
\hline
\end{tabular}

The abundance of plankton in the research station was represented in Table 1. The six research stations indicated that the highest abundance was at station 3 as many as 19,668 cell $L-1$ and the lowest abundance was at stations 4 as much as 6,121 cell $L^{-1}$.The research location was mostly rivers area the flow played an important role in determining the type and abundance of plankton. Current speed could also affect the types of plankton organisms that live in aquatic. The plankton that dominated the observations station was 
Synedra. According Round (1964) in Wijaya (2009) that the type of aquatic communities that have current $<0.2-1 \mathrm{~ms}^{-1}$ is dominated by plankton such as Nitzschia, Navicula, Synedra, Oscillatoria.

The results of the analysis in Figure 3,4 and 5 showed the similarities of natural food in the intestines of $M$. padangensis with the availability of natural plankton in the aquatic (Table 1). It indicated that that bilih fish was not selective consuming food. Thus Bilih fish consumed natural food that was available in the aquatic.

\section{Conclusion}

Natural food of $M$. padangensis in Naborsahan River and Toba lake was the same that the phytoplankton of the Bacillariophyceae Class. M. padangensis when migratory still did meal activities. M. padangensis actively feed (feeding habits) during the day or diurnal. Natural food $M$. padangensis were phytoplankton, among others Rhizosolenia, Synedra, Gonatozygon, Closterium, Surirella, Pinnularia, Oscillatororia, Melosira, Gyrosigma, Aulacoseira and one Zooplankton is Daphnia and also Macrozoobentos among others Creseis and Tubifex. The type of natural foods that most commonly found was phytoplankton from the Synedra genus whose Index of Preporedance (IP) $>40 \%$, was $98.9 \%$. Based on the composition of dominant food, $M$. padangensis was classified as plankton feeder.

\section{References}

Adjie, S. 2009. Sebaran dan Kebiasaan Makan Beberapa Jenis Ikan di DAS Kapuas Kalimantan Barat. Seminar Nasional Tahunan VI Hasil Penelitian Perikanan dan Kelautan. Balai Riset Perikanan Perairan Umum Palembang. Palembang.

[APHA] American Public Health Association. 2005. Standard Methods for The Examination of Water and Wastewater. United Book Press Inc, Maryland.

Edmonsond, W.T. 1959. Freshwater Biology $2^{\text {nd }}$.University of Washington, Seattle.

Effendi, H. 2003. Telaah Kualitas Air bagi Pengelolaan Sumberdaya dan Lingkungan Perairan. Kanisius, Yogyakarta.

Effendie, M.I. 1979. Metode Biologi Perikanan. Yayasan Dewi Sri. Bogor. 112pp.

Effendie, M.I. 1997. Biologi Perikanan. Yayasan Pustaka Nusatama. Yogyakarta. 163 pp.
Febriani, L. 2010. Studi Makanan dan Pertumbuhan Ikan bilih (Mystacoleucus padangensis Bleeker) di Danau Singkarak, Sumatera Barat. [Tesis]. Institut Pertanian Bogor. Bogor. 102 pp.

Hyslop, E.J.1980. Stomach Content Analysis-a review of methods and Their Application. Journal fish Biology 17:411-429.

Kartamihardja, E.S., Sarnita, A.S. 2010. Populasi Ikan Bilih di Danau Toba: Keberhasilan Introduksi Ikan Dan Implikasi Pengelolaan dan Prospek Masa Depan. Pusat Riset Perikanan Tangkap, Badan Riset Kelautan dan Perikanan, Departemen Kelautan dan Perikanan. 50 pp.

Kottelat, M., Whitten, A.J., Kartikasari, S.N., Wirjoatmodjo, S. 1993. Freshwater fishes of Western Indonesia and Sulawesi. Periplus Editions. Hongkong. $221 \mathrm{pp}$.

Natarjan, A.V., Jhingran A.G.1961. Index of preponderance a method of grading the food element in the stomach analysis of fishes. Indian Journal Fish 8 (1):54-59)

Nikolsky, G.V. 1963. The Ecology of Fishes. Academy press. New York. 432 pp.

Purnomo, K., Kartamihardja, E.S. 2008. Selamatkan Ikan Bilih Sekarang juga atau Biarkan Punah. Badan Riset Kelautan dan Perikanan. Departemen Kelautan dan Perikanan Sumatera Barat. Padang.

Purnomo, K., Sunarno, M.T. 2009. Beberapa Aspek Biologi Ikan Bilih (Mystacoleucus padangensis) di Danau Singkarak, Sumatera Barat. Bawal, Widya Riset Perikanan Tangkap 2 (6): 265-271.

Sachlan. 1982. Planktonology. Fakultas Peternakan dan Perikanan, Universitas Diponegoro. Semarang.

Simanjuntak, C.P.H., Rahardjo, M.F. 2008. Variasi Makanan Ikan Petek (Leognathus equulus Forsskal,1775) di Pantai Mayangan, Jawa Barat. Prosiding Seminar Nasional Hasil-Hasil Penelitian Perikanan dan Kelautan. Jurusan Perikanan Fakultas Pertanian, UGM. Yogyakarta. MII:1-9.

Sinaga, E. L. R., Muhtadi, A., Bakti, D. 2016. Profil Suhu, Oksigen Terlarut, dan $\mathrm{pH}$ Secara Vertikal Selama 24 Jamdi Danau Kelapa Gading Kabupaten Asahan 
Sumatera Utara. Omni-Akuatika 12 (2): $114-124$

Situmorang, T.S. 2013. Studi Komparasi Jenis Makanan Ikan Keperas (Puntius binotatus) di Sungai Aek Pahu Tombak, Aek Pahu Hutamosu dan Sungai Parbotikan Kecamatan Batang Toru Tapanuli Selatan. [Tesis]. Universitas Sumatera Utara. Medan. 65 pp.

Sulistiyarto, B. 2012. Hubungan Panjang Berat, Faktor Kondisidan Komposis i Makanan Ikan Seluang (Rasboraa rgyrotaenia Blkr) di Daratan Banjir Sungai Rungan Kalimantan Tengah. Jurnal IImu HewanTropika 1 (2): 62-66.

Taufiqurohman, A., Nurruhwati, I., Hasan, Z. 2007. Kebiasaan Makan Ikan (Food Habits) Ikan Nilem (Osteochilus) di Tarogong, Kabupaten Garut. Universitas Pajajaran. Bandung.

Tresna, L.K., Dhahiyat, Y., Herawati, T. 2012. Kebiasaan Makanan dan Luas Relung Ikan Di Hulu Sungai Cimanuk Kabupaten
Garut,

Jawa

Barat. JurnalPerikanandanKelautan. 3 (3): 163 $-173$.

Umar, C., Kartamihardja, E.S. 2011. Hubungan Panjang-Berat Kebiasaan Makandan Kematangan Gonad Ikan Bilih (Mystacoleucus padangensis Bleeker) di Danau Toba. Sumatera Utara. Jurnal Bawal 3 (6): 351-356.

Wijaya, H.K. 2009. Struktur Komunitas Perifiton dan Plankton serta Parameter FisikaKimia Perairan sebagai Penentu Kualitas Air di Bagian Hulu Sungai Cisadane, Jawa Barat. Departemen Manajemen Sumberdaya Perairan Fakultas Perikanan dan IImu Kelautan, Institut Pertanian Bogor. Bogor.

Yuliati., Riani, E., Pramudya, N B., Fahrudin, A. 2017. The Quality of Water of the Downstream of the Siak River, Riau Province, Based on Tidal Condition. Omni-Akuatika 13 (1): 66-77. 